\title{
The Effects of Environment, Feed Form and Dietary Caloric Density on Broiler Performance; and Effect of Variable CatP Ratio and Phytase on Growth performance and Mineral Deposition in Corn-Soy Diets fed to Straight-run Broilers
}

Brian G. Glover

Follow this and additional works at: https://researchrepository.wvu.edu/etd

\section{Recommended Citation}

Glover, Brian G., "The Effects of Environment, Feed Form and Dietary Caloric Density on Broiler Performance; and Effect of Variable CatP Ratio and Phytase on Growth performance and Mineral Deposition in Corn-Soy Diets fed to Straight-run Broilers" (2017). Graduate Theses, Dissertations, and Problem Reports. 5681.

https://researchrepository.wvu.edu/etd/5681

This Dissertation is protected by copyright and/or related rights. It has been brought to you by the The Research Repository @ WVU with permission from the rights-holder(s). You are free to use this Dissertation in any way that is permitted by the copyright and related rights legislation that applies to your use. For other uses you must obtain permission from the rights-holder(s) directly, unless additional rights are indicated by a Creative Commons license in the record and/ or on the work itself. This Dissertation has been accepted for inclusion in WVU Graduate Theses, Dissertations, and Problem Reports collection by an authorized administrator of The Research Repository @ WVU.

For more information, please contact researchrepository@mail.wvu.edu. 
The Effects of Modest Improvement in Pellet Quality on Tom Turkey and Straight-run Broiler Performance, with Focus on Experimental Design.

\title{
Brian Gregory Glover
}

Thesis submitted to the

Davis College of Agriculture, Natural Resource and Design

at

West Virginia University

In partial fulfillment of the requirements for the degree of

\author{
Master of Science \\ In \\ Nutrition and Food Science \\ Joseph S. Moritz, Ph.D., Chairperson \\ Janet Tou, Ph.D. \\ Kenneth Blemings, Ph.D. \\ Division of Animal and Nutritional Sciences \\ Morgantown, West Virginia \\ 2015
}

Keywords: Feed form, pellet quality, turkey performance, crumble, broiler performance

2015 Brian G. Glover 


\begin{abstract}
THE EFFECTS OF MODEST IMPROVEMENT IN PELLET QUALITY ON TOM TURKEY AND BROILER PERFORMANCE, WITH FOCUS ON EXPERIMENTAL DESIGN.
\end{abstract}

\title{
BY BRIAN G. GLOVER
}

Improving the crumble/pellet percentage of feed has been argued to be difficult to obtain in the commercial industry due to the necessity of feed mills producing adequate feed volume within a time constraint. Poultry research often utilizes small numbers of birds per pen or experimental unit that may affect the estimation of variance components, potentially producing pen performance metrics that are less valuable for industry guidance. In Experiment 1, diets were manufactured to maintain nutrient availability and vary only in crumble/pellet percentage (standard $=40 \%$ pellets, improved $=70 \%$ pellets). The two dietary treatments were then fed to Hybrid Converter male turkeys from d 1-126. Growth performance variables were measured and carcass characteristics (breast wt. and yield) were determined. Average pen weight increased by $0.17 \mathrm{~kg}(P=0.02)$ and tended to decrease feed conversion ratio by 11 -points $(P=0.07)$ for toms fed improved quality pellets. Experiment 2, was designed to determine the effects of pen size and crumble/pellet percentage on commercial broiler performance using a 2 (feed quality) x 2 (pen size) factorial treatment arrangement in a randomized complete block design. Feed manufacture was manipulated to maintain nutrient availability constant with treatments differing only in crumble/pellet percentages (standard $=50 \%$ pellets, improved $=70 \%$ pellets). Growth performance was analyzed at the end of each growth phase (starter d 1-10, grower d 11-21, finisher d 22-38). Carcasses characteristics of hot breast weight and yield were determined on $\mathrm{d}$ 38. No interactions were observed for the d1-38 growth period $(P>0.05)$. Broilers consuming improved crumble/pellet percentage had a tendency towards decreased feed intake $(P=0.07)$ and feed conversion ratio by 3 points $(P=0.1)$, but maintained a similar weight gain $(P=0.3)$. Large pens tended to decrease live weight gain $(\mathrm{P}=0.06)$. Improved (crumble/pellet) percentage increased pen coefficient of variation for within pen ending weight $(P=0.05)$, likely due to competitive feeding behavior. These experiments suggest that a modest improvement to pellet quality improves both tom turkey and broiler performance, and a small pen model may produce sufficient results for broiler chicken research. 


\section{Acknowledgements}

I would like to first thank my mentor and advisor, Dr. Joseph Moritz for the support and guidance he has provided me throughout my collegiate career. I am grateful for the opportunities he has provided me throughout these past years. The people and connections I have made will allow for continued success within my career. Next, I would like to thank my committee members, Drs. Janet Tou and Kenneth Blemings for their constant support throughout my research. I would also like to thank all the WVU staff and faculty for all the help they have provided me. Research is very labor intensive; therefore, I would like to extend my sincerest gratitude towards my fellow lab mates for all of their support throughout this experience: John Boney, Mark Lemons, Dr. Ashley Evans, and Danielle Reese. Without their help, none of this would be possible. Lastly, I would like to thank my family: my parents Ben and Debra; my brothers Brent and Brandon; my sisters Breena, Britteny, and Brooke; along with my nieces and nephews. Without their support, patience, and constant motivation I would have never made it to this pinnacle in my life. 


\section{Table of Contents}

ABSTRACT

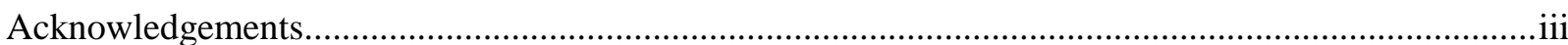

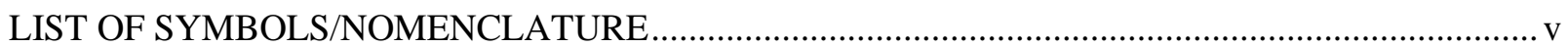

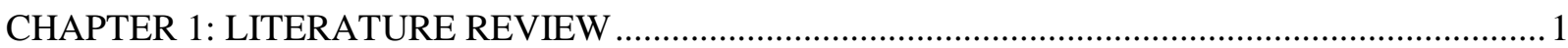

Commercial Broiler and Turkey Production in West Virginia ........................................................... 1

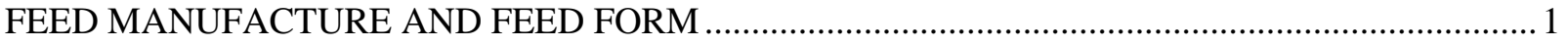

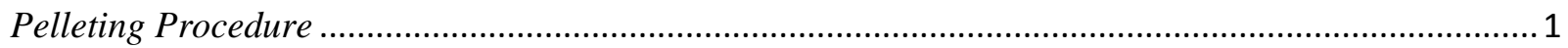

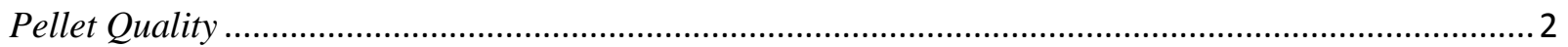

PELLET QUALITY AND MEAT BIRD PERFORMANCE .............................................................. 3

TURKEYS AND THE DIFFERENCE FROM BROILERS ..................................................... 4

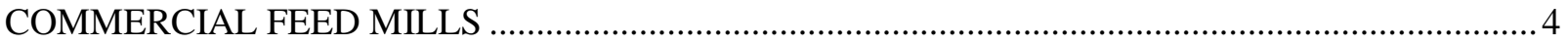

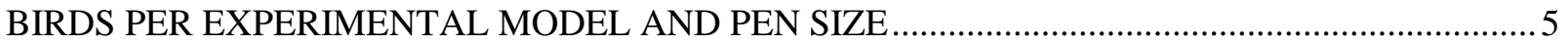

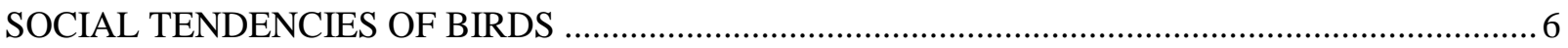

CHAPTER 2: MANUSCRIPT PREPARED FOR JOURNAL OF APPLIED POULTRY RESEARCH: EFFECTS OF MODEST IMPROVEMENTS IN PELLET QUALITY AND EXPERIMENT PEN SIZE

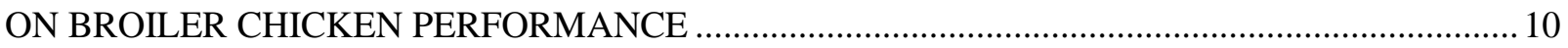

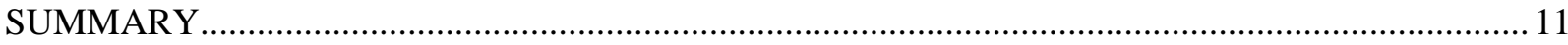

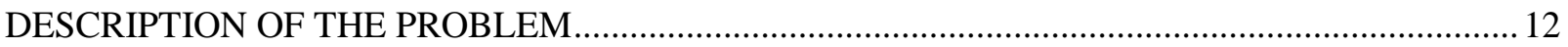

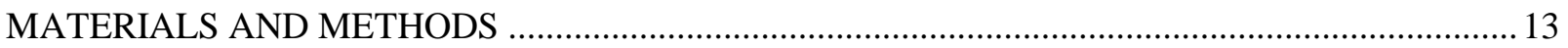

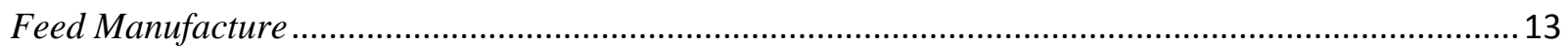

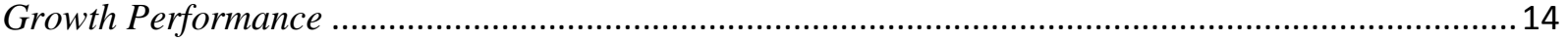

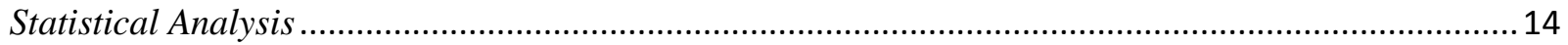

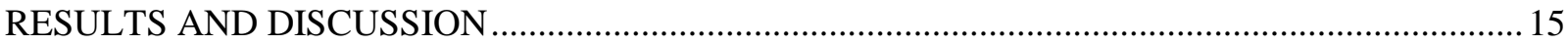

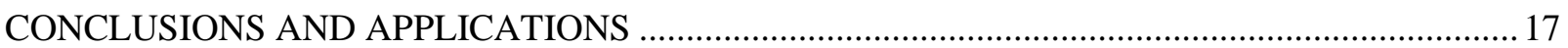

CHAPTER 3: MANUSCRIPT PREPARED FOR JOURNAL OF APPLIED POULTRY RESEARCH: THE EFFECTS OF MODEST IMPROVEMENT TO PELLET QUALITY ON TOM TURKEY

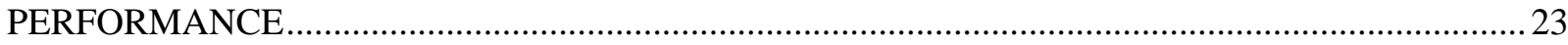

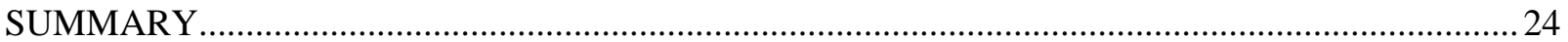

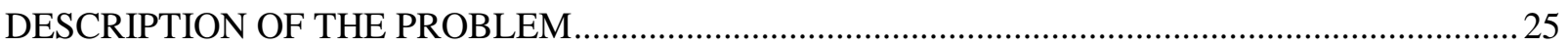

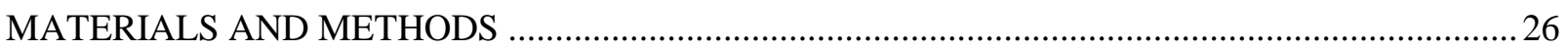

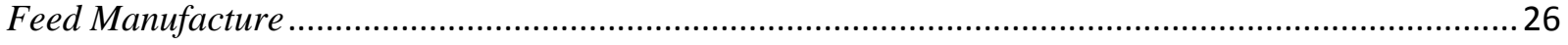

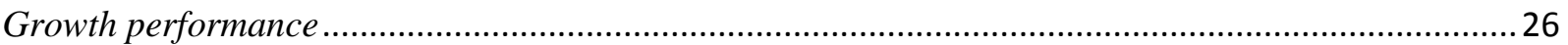

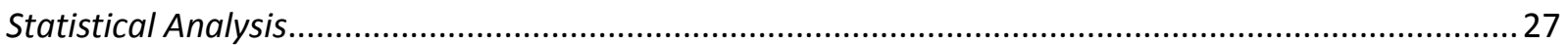




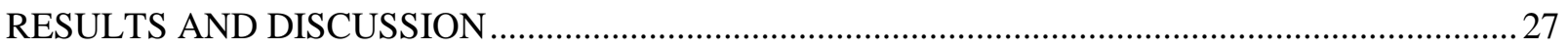

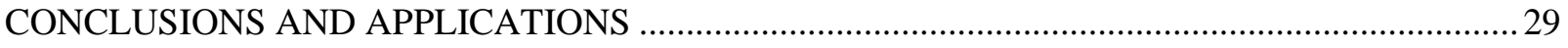

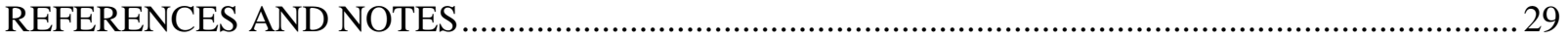

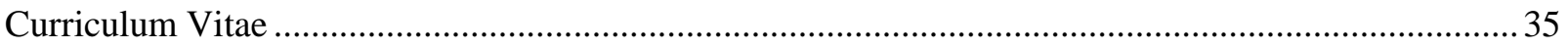

\section{LIST OF TABLES}

CHAPTER 2: MANUSCRIPT PREPARED FOR JOURNAL OF APPLIED POULTRY RESEARCH: EFFECTS OF MODEST IMPROVEMENTS IN PELLET QUALITY AND EXPERIMENT PEN SIZE ON BROILER CHICKEN PERFORMANCE …................................................................................ 10

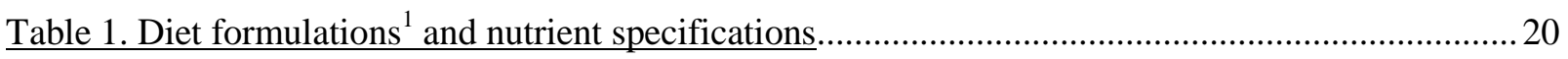

Table 2. Manufacturing variables and pellet quality for growth periods ...............................................2

Table 3. Effects of Feed Form and Pen Size on D 1-38 Broiler Performance and Carcass Quality........22

CHAPTER 3: MANUSCRIPT PREPARED FOR JOURNAL OF APPLIED POULTRY RESEARCH: THE EFFECTS OF MODEST IMPROVEMENT TO PELLET QUALITY ON TOM TURKEY

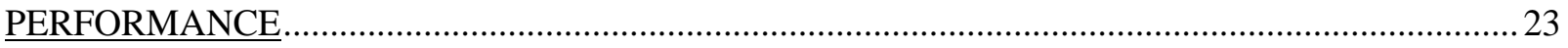

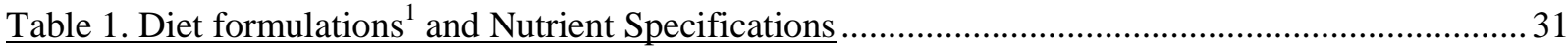

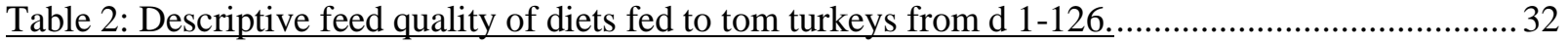

Table 3: Effect of feed quality (standard vs. improved) on tom turkey performance from d 1-126........33

Table 4: Descriptive processing plant data for d 1-126 tom turkeys.

\section{LIST OF SYMBOLS/NOMENCLATURE} CHAPTER 1

1. Live Weight Gain - LWG

2. Feed Intake - FI

3. Feed Conversion Ratio - FCR

4. Pellet Durability Index - PDI

5. Modified Pellet Durability Index - MPDI

6. American Society For Testing And Materials - ASTM

\section{CHAPTER 2}

1. American Society For Testing And Materials - ASTM

2. Live Weight Gain - LWG 
3. Feed Intake - FI

4. Feed Conversion Ratio - FCR

5. Nonphytate Phosphorus - nPP

6. Mixer-Added Fat - MAF

7. Pellet Durability Index - PDI

8. Modified Pellet Durability Index - MPDI

9. Ending Body Weight - EBW

10. Analysis Of Variance - ANOVA

11. Standard Error of the Mean - SEM

12. General Linear Model - GLM

13. Statistical Analysis System - SAS

14. Least Significant Difference - LSD

15. Coefficient Of Variation - CV

16. Metabolized Energy - ME

17. New Holman Pellet - NHP

\section{CHAPTER 3}

1. American Society For Testing And Materials - ASTM

2. Live Weight Gain - LWG

3. Feed Intake - FI

4. Feed Conversion Ratio - FCR

5. Calcium Lignosulfonate - CaLS

6. Nonphytate Phosphorus - nPP

7. Mixer-Added Fat - MAF

8. Pellet Durability Index - PDI

9. Modified Pellet Durability Index - MPDI

10. Ending Body Weight - EBW

11. Analysis Of Variance - ANOVA

12. General Linear Model - GLM

13. Statistical Analysis System - SAS 


\section{CHAPTER 1: LITERATURE REVIEW}

\section{Commercial Broiler and Turkey Production in West Virginia}

West Virginia produced 94 million broilers, resulting in 376 million pounds of meat, which had a production value of 188 million dollars in 2012. West Virginia, in 2013, increased production to 96.8 million broilers, 387 million pounds of meat, at a production value of 234 million dollars. Broiler production within West Virginia has made increases in all areas and is continuing to increase every year. Broiler data represent annual estimates taken from a period beginning on December 1 and continuing through November 30. West Virginia raised 3.3 million turkeys, produced 89.1 million pounds of meat, resulting in a production value of 64.2 million dollars in 2012. There were similar statics observed in 2013 with 3.1 million turkeys raised, 80.6 million pounds of meat produced, all at a production value of 53.6 million dollars. Turkey statistics were based on turkeys that were placed on September 1 through August 31. This statistical analysis ranked West Virginia $19^{\text {th }}$ in broiler production and $13^{\text {th }}$ in turkey production in total U.S. comparison [1].

\section{FEED MANUFACTURE AND FEED FORM}

\section{Pelleting Procedure}

Feed is the major cost associated with a commercial poultry grower's budget. This is due to the fact that feed represents $60-70 \%$ of the total production cost for a commercial poultry grower, and the price of ingredients accounts for the major quantity of the total feed cost. Pelleting feed has been known to be a more costly form of processing; but pelleting a diet has been shown to increase live weight gain (LWG), increase feed intake (FI), and decrease feed conversion ratio (FCR), and decrease feed wastage [2-9]. The feed manufacture process consists of combining raw materials through batching, mixing, grinding, steam conditioning, pelleting, 
24 cooling, and packaging [10]. All of these elements singularly or in combination can affect bird 25 performance and health.

The process of pelleting has been defined as the agglomeration of smaller

27 particles into larger particles through a mechanical process combining moisture (through steam),

28 heat, and pressure [2-11]. Cereal grains (corn, wheat, barley, etc...), which can be part of a

29 poultry diet formulation, are typically ground before being mixed allowing for improved

30 blending and decreasing mixing problems [3,12]. The process of grinding is also known as

31 particle size reduction [10]. Once the ingredients are ground and mixed they are then conditioned

32 with steam at an average temperature of $80-90^{\circ} \mathrm{C}$, and extruded through a pellet die. The hot

33 pellet is next conveyed through a cooling deck, once through the cool deck the pellets can either

34 be packaged or pass through a roller mill to reduce size to a crumble and then be packaged

$35[10,13]$. The final product is then transported to poultry barns and augured into feed pans for

36 broiler or tom turkey consumption.

37 Pellet Quality

38 Pellet quality is the capability a pellet has to preserve integrity after manufacture

39 and through mechanical stressors associated assisted with transportation and handling [13-14].

40 The physical quality of pellets can be determined through pellet durability index (PDI), modified

41 pellet durability index (MPDI), particle size, and percentage of pellets to fines. The PDI and

42 MPDI are found by sifting a 500 gram sample through an American Society for Testing and

43 Materials (ASTM) sieve based on pellet die diameter, placing it into a Pfost tumbling box for 10

44 minutes, removing the sample and sieving it again, then finally calculating the final weighed

45 sample. Particle size is determined by placing a 100 gram representative sample into a Ro-Tap

46 machine for 10 minutes; the sample is then removed and each sieve was weighed and recorded. 
47 The percentage of pellets to fines ratio is determined through sifting a representative sample through the appropriate ASTM sieve to receive the proper percentage of pellets, and then through a second ASTM sieve to receive the appropriate percentage of fines. The feed remaining 50 on the first sieve is considered pellets; the sample of feed that passes through the first sieve is crumbles, while the remaining feed sample that passes through the second sieve is considered

fines. The weight of the pellets, crumbles, and fines is then used to calculate the percentage of pellet to fine ratio by using the total weight of the representative sample [14-15]. These data provide a comprehensive view of pellet quality.

\section{PELLET QUALITY AND MEAT BIRD PERFORMANCE}

Previous studies confirm that feeding whole or intact pellets to meat birds can improve growth performance metrics such as decreasing FCR and increasing LWG. Proudfoot and Hulan [16] found that presenting a higher percentage of fines to turkeys demonstrated a negative effect on FCR and body weight gain [16]. These results are similar to that of a study done by Lilly et al [2] that found for every 10-percentage-point increase in whole pellets there was a 0.4-point improvement in FCR and breast weight, while increasing FI [2]. Plavnik et al [17] noticed that pelleted feed resulted in a moderate improvement to FCR and an increased growth response in both turkeys and broiler chicks regardless of age [17]. Pelleting diets may be a more expensive pelleting technique, but the improved bird growth performance has been viewed to out-weigh manufacturing cost. Lilly et al. [2] also examined the economic returns based on feed costs and bird performance. These authors found that broilers fed a high pellet quality (90:10 pellet:fine) diet achieved a low FCR and high carcass weight, indicating production savings relative to a ground pellet diet of $\$ 0.05$ to $\$ 0.03 / \mathrm{kg}$ of carcass weight [2]. Through these and other previous 
research papers it is clear that growth performance will improve from feeding a pelleted diet, with a low percentage of fines.

\section{TURKEYS AND THE DIFFERENCE FROM BROILERS}

Turkeys and broilers are both produced for human consumption. Tom turkeys are typically reared longer than broilers, due to turkeys taking longer to mature. Turkeys generally go to market between 15 and 25 weeks of age (105 d to $175 \mathrm{~d}$ ). These turkeys typically weigh around 35-40 pounds at 20 weeks of age. Broilers reach maturity much sooner, and are typically reared from 5 to 8 weeks ( $35 \mathrm{~d}$ to $55 \mathrm{~d}$ ). Broilers are not placed on pellets until the finisher phase, whereas turkeys can be placed on pellets during the grower and finisher phases. Performance differences associated with feeding pellets have been noticed to be numerically greater for turkeys than broilers, possibly due to the increased grow out time. A study conducted by Wamsley and Moritz [18] determined that feeding a diet of high quality pellets (average of $78.64 \%$ pellets $)$ fed from $\mathrm{d} 42-118$ produced toms that were $0.29 \mathrm{~kg}(0.64 \mathrm{lb})$ per bird heavier with 9 points lower FCR, as compared to toms fed a diet of ground pellets. Regression analyses predicted that if toms fed a ground pelleted diet finished at the same d 118 ending weight as turkeys fed a diet of high quality pellets the FCR advantages of the high quality pellet diet would be 12 points [18]. Improvement of FCR by 12 points (a point is considered a 0.01 difference) is of greater magnitude compared to pelleting research conducted on broilers. For example, the previous broiler study conducted by Lilly et al. [2] found a 4 point improvement to FCR.

\section{COMMERCIAL FEED MILLS}

A survey of local commercial feed mill production was taken by Dr. Moritz in 2007 [18]. This survey compared the manufacturing techniques: conditioning time and temperature, 
92 production rate (ton/week), die size, and the typical PDI manufactured in three local commercial

93 feed mills. The first mill demonstrated a conditioning time and temperature of 35 seconds at

$9490.5^{\circ} \mathrm{C} ; 16,400$ ton/week; a 7 x $3 \mathrm{~mm}$ of die used; and an average PDI of $75 \%$. The second mill

95 demonstrated a conditioning time and temperature of 20 seconds at $82.2^{\circ} \mathrm{C} ; 1,000$ ton/week; an

$9611 \times 2 \mathrm{~mm}$ of die used; and an average PDI of 70\%. The final mill surveyed demonstrated a

97 conditioning time and temperature of 4 seconds at $68.3^{\circ} \mathrm{C} ; 1,000$ ton/week; a $13 \times 1 \mathrm{~mm}$ of die

98 used; and an average PDI of 95\%. This survey of surrounding commercial feed manufacturing

99 techniques demonstrates that there is no standard manufacturing technique when it comes to feed

100 manufacture [18].

101

102

103

104

105

106

107

108

109

110

111

112

113

114

\section{BIRDS PER EXPERIMENTAL MODEL AND PEN SIZE}

Broiler performance research often utilizes small numbers of birds per pen or experimental unit that may affect the estimation of variance components, potentially producing pen performance metrics that are less valuable for industry guidance. University research typically rears birds in a more controlled environment than that of a commercial setting. These controlled environments may produce data that is less applicable to the commercial industry. Researchers often utilize experimental units based on research barn resources and budget constraints. Through the use of power curves an investigator may decrease research cost and increase probability of correctly assessing treatment comparisons. Power curves aid in predictions of proportion for experiments yielding a designated level of significance as the differences between two means increases [19]. Shim and Pesti [20] found that the larger the sample size the smaller the sampling error; however they also found that the sample size only has

to be large enough to produce reasonable accuracy and having excessive sample size increases cost and time [20]. Cravener et al [21] stated that a commercial poultry house presents social 
115 interactions that may be different from pens housing only 20 to 42 birds [21]. Shim and Pesti

116 [20] found that more replications generally produce improved results in comparison to more

117 birds per pen [20]. Social interactions or tendencies among an increased number of birds may

118 produce increased variations among individual bird weights.

\section{SOCIAL TENDENCIES OF BIRDS}

Most researchers and commercial growers have noticed that poultry exhibit behavioral tendencies when placed into a group. The formation of "pecking orders" among birds is usually determined through stronger birds being more dominant over weaker birds. The level of competition among group members is usually dictated by the ease of access to resources because of dominance relationships [22-30]. Resources located in one exclusive area may allow for dominant individuals to control access to those resources forcing subordinates (weaker birds) to wait [22-30]. Leone and Estévez [22] observed increased aggression in larger group sizes when birds had to compete for limited access to resources, and that a greater number of birds were excluded from feeders at any given time during a restricted feeding phase [22]. These data suggest that group hierarchies may exist, but are more prominent when resources are restricted.

When conducting poultry research it is important for scientists to consider many facets that can affect performance: pellet quality, experimental model specific to pen size, and social hierarchies. By considering these factors, research can better assess growth performance and ultimately increase applicability to the commercial industry. 
1.USDA, National Agriculturre Statistics Service. (2014). Poultry-Production and Value 2013 Summary (April 2014). United States Department of Agriculture. doi:ISSN: 1949-1573

2.Lily, K.G.S.; Gehring, C.K.; Beaman, K.R.; Turk, P.J.; Sperow, M.; and Moritz, J.S.(2011). Examing the relationships between Pellet Quality, Broiler Performance, and Bird Sex. J. Appl. Poult. Res., 20, 231-239.

3.Behnke, K. C. 1996. Feed manufacturing technology: Current issues and challenges. Anim. Feed Sci. Technol. 62:49-57.

4.Jensen, L. S., L. H. Merrill, C. V. Reddy, and J. Mc-Ginnis. 1962. Observations on eating patterns and rate of food passage of birds fed pelleted and unpelleted diets. Poult. Sci. 41:1414-1419.

5.Hott, J. M., N. P. Buchanan, S. E. Cutlip, and J. S. Moritz. 2008. The effect of moisture addition with a mold inhibitor on pellet quality, feed manufacture, and broiler performance. J. Appl. Poult. Res. 17:262-271.

6.Moritz, J. S., R. S. Beyer, K. J. Wilson, K. R. Cramer, L. J. McKinney, and F. J. Fairchild. 2001. Effect of moisture addition at the mixer to a corn-soybean based diet on broiler performance. J. Appl. Poult. Res. 10:347-353.

7.Nir, I., Y. Twina, E. Grossman, and Z. Nitsan. 1994. Quantitative effects of pelleting on performance, gastrointestinal tract and behavior of meat-type chickens. Br. Poult. Sci. 35:589-602.

8.Behnke, K. C. 1994. Factors affecting pellet quality. Pages 44-54 in Proc. Maryland Nutr. Conf., College Park, MD. Maryland Feed Ind. Counc. and Univ. Maryland, College Park.

9.Scheideler, S. E. 1991. Pelleting is important for broilers. Pages 1-7 in Proc. 18th Annu. Carolina Poult. Nutr. Conf., Charlotte, NC. North Carolina State Univ., Raleigh.

10. M.R. Abdollahi, V. Ravindran, B. Svihus (2012). Pelleting of broiler diets: An Overview with Emphasis on pellet quality and nutritional value. Animal Feed Science and Technology, 179, 1-23.

11. Buchanan, N. P., K. G. S. Lilly, and J. S. Moritz.2010. The effects of altering diet formulation and manufacturing technique on pellet quality. J. Appl. Poult. Res.19:112-120.

12. Koch, K. 1996. Hammermills and rollermills. MF-2048 Feed Manufacturing. Dept. Grain Sci. Ind., Kansas State Univ., Manhattan. 
13. Fairfield, D., Thomas, H., Garrison, R., Bliss, J., Behnke, K. Pelleting. in: E.K. Schofield (Ed.) Feed Manufacturing Technology V. American Feed Industry Association, Arlington; 2005:142-167

14. Cramer, K. R., K. J. Wilson, J. S. Moritz, and R. S. Beyer. 2003. Effect of sorghum-based diets subjected to various manufacturing procedures on broiler performance. J. Appl. Poult. Res. 12:404-410.

15. American Society for Agricultural Engineers. 1983. Methods for determining and expressing fineness of feed materials by sieving. Page 325 in American Society of Agricultural Engineers Standard S 319. Am. Soc. Agric. Eng. Yearbook Standards, Am. Soc. Am. Eng., St. Joseph, MI. Pellet durability index was determined by sifting $500 \mathrm{~g}$ of pellets from a treatment through a No. 6 American Society for Testing and Materials (ASTM) screen before being deposited into a Pfost tumbler. The sifted pellets were then tumbled in the container, dimensions $5 \times 12 \times 12$ in., with a $2 \times 9$ in. plate fixed diagonally along the $12 \times 12 \mathrm{in}$. side, for approximately $10 \mathrm{~min}$ at $50 \mathrm{rpm}$. The sample was then sifted again through the No. 6 (ASTM) mm screen, weighed, and the percentage of pellets was calculated by dividing the weight of pellets after tumbling by the weight of pellets before tumbling and then multiplying that value by 100 . Modified pellet durability index was similarly measured, with the exception of the addition of five, 13-mm hexagonal bolts to the $500 \mathrm{~g}$ of sample in the tumbler. Both analyses are meant to simulate the deleterious effects of transferring and handling the pellets.

16. Proudfoot, F.G. and H.W. Hulan. 1982. Feed Texture on the Performance of Turkey Broilers. J. poultry Science. 61:327-330.

17. Plavnik, I., E. Wax, D. Sklan, and S. Hurwitz, 1997. The response of broiler chickens and turkey poults to steam-pelleted diets supplemented with fat or carbohydrates. Poultry Sci. 76:1006-1013.

18. J.S. Moritz and K.G.S. Lilly. 2007. Production Strategies and Feeding Opportunities for Pellets of High Quality. Blue and Gold Presentation at West Virginia University. Presented on April 8, 2008.

19. Wamsley, K.G.S. 2012. Strategies to maximize feed quality and poultry performance. Dissertation published by West Virginia University.

20. Pesti, G.M. and M.Y. Shim. 2012. A spreadsheet to construct power curves and clarify the meaning of the word equivalent in evaluating experiments with poultry. J. Poultry Science. 91:2398-2404. 
21. Shim, M.Y. and G.M. Pesti. 2014. The use of a pen size optimization workbook for experiment research design using the Visual Basic for Applications in Excel for poultry.J. Appl. Poult. Res. 23:315-322.

22. Cravener, T.L., Roush, W.B., and M.M. Mashaly. 1992. Broiler Production Under Varying Population Densities. J. Poultry Science. 71:427-433.

23. Leone, E. H., and I. Estevez. 2008. Space use according to the distribution of resources and level of competition. Poult. Sci. 87:3-13.

24. King, M. G. 1965. Disruptions in the pecking order of cockerels concomitant with degrees of accessability to feed. Anim. Behav. 13:504-506.

25. Banks, E. M. 1984. Relations between aggressive social dominance and resource utilization in domestic fowl. Polit. Psychol. 5:617-622.

26. Caraco, T., C. Barkan, J. L. Beacham, L. Brisbin, S. Lima, A. Mohan, J. A. Newman, W. Webb, and M. L. Withiam. 1989. Dominance and social foraging: A laboratory study. Anim. Behav. 38:41-58.

27. Keeling, L. 1995. Spacing behavior and an ethological approach to assessing optimum space allocations for groups of laying hens. Appl. Anim. Behav. Sci. 44:171-186.

28. Pagel, M., and M. S. Dawkins. 1997. Peck orders and group size in laying hens: 'Futures contracts' for non-aggression. Behav. Process. 40:13-25.

29. Stahl, J., P. H. Tolsma, M. J. J. E. Loonen, and R. H. Drent. 2001. Subordinates explore but dominants profit: Resource competition in high Arctic barnacle goose flocks. Anim. Behav. 61:257-264.

30. Dubois, F., L. A. Giraldeau, and J. W. A. Grant. 2003. Resource defense in a groupforaging context. Behav. Ecol. 14:2-9.

31. Banks, E. M., D. G. M. Wood-Gush, B. O. Hughes, and N. J.Mankovich. 1979. Social rank and priority of access to resources in domestic fowl. Behav. Proc. 4:197-209. 

EXPERIMENT PEN SIZE ON BROILER CHICKEN PERFORMANCE

228

229

230

231

232

233

234

235

236

237

238

239

240

241

242

243

$244 \quad{ }^{1}$ Corresponding Author: Joe.Moritz@mail.wvu.edu

245 Primary Audience: Researchers, Nutritionists, Feed Mill Managers
Metabolism and Nutrition
B.G. Glover* and J.S. Moritz*1

*Department of Animal and Nutritional Sciences, Davis College of Agriculture, Natural Resources and Design, West Virginia University, Morgantown, WV 26506

246 
SUMMARY: Improving the crumble/pellet percentage of feed has been argued to be difficult to obtain in the commercial industry due to the necessity of feed mills producing adequate feed volume within a time constraint. Broiler performance research often utilizes small numbers of birds per pen or experimental unit that may affect the estimation of variance components, potentially producing pen performance metrics that are less valuable for industry guidance. The objective of this study was to compare the performance of straight run Hubbard $\mathrm{x}$ Cobb broiler chickens receiving a standard crumble/pellet percentage (50\%) vs a modestly improved crumble/pellet percentage (70\%), in either large pen (46 birds) or small pen (23 birds) experimental units. All diets were batched, mixed, steam conditioned to approximately $82^{\circ} \mathrm{C}$, extruded through a $4.8 \times 38.1 \mathrm{~mm}$ pellet die, and crumbled at the West Virginia University pilot feed mill. Crumble/pellet percentage differences were obtained by grinding a portion of the complete feed then remixing. Treatments were replicated 10 times and fed for 1-38 d using a $2 \mathrm{x}$ 2 factorial arrangement in a randomized complete block design to measure growth performance. Bird density and feeder space access was $0.06 \mathrm{~m}^{2} / \mathrm{bird}$ and $1.2 \mathrm{~cm} / \mathrm{bird}$, respectfully for both experimental units. Crumble/pellet percentage and pen size main effects did not interact for any growth performance metric. Broilers consuming improved crumble/pellet percentage had a tendency towards decreased feed intake $(\mathrm{P}=0.07)$ and feed conversion ratio by 3 points $(\mathrm{P}=0.1)$, but maintained a similar weight gain $(\mathrm{P}=0.3)$. Large pens decreased live weight gain $(\mathrm{P}=0.03)$. Improved crumble/pellet percentage increased pen coefficient of variation for ending weight $(\mathrm{P}=0.05)$, likely due to competitive feeding behavior. These data suggest that modest improvements in crumble/pellet percentage may provide performance benefits, and feed quality variation effects on growth performance can be satisfactorily evaluated utilizing a small pen experimental unit. 
Keywords: crumble, pellet, broiler, pen size, feed conversion ratio

271

272

273

274

275

276

277

278

279

280

281

282

283

284

285

286

287

288

289

290

291

292

\section{DESCRIPTION OF THE PROBLEM}

Pelleting feed has been shown to increase feed intake (FI), increase live weight gain (LWG), and decrease feed conversion ratio (FCR) [1], thus justifyng the expense of pelleting. Broiler growth response to feed has importance to commercial integrators since feed and feed manufacture constitute 60 to $70 \%$ of production cost. Additional benefits of pelleting include the potential to decrease pathogens in feed and improve feed flow [1-8]. Past research has described that maintaining equivalent nutrient availability is important in pelleting research. Lilly and coauthors [9] studied variations of pellets and fines on broiler chickens, while maintaining similar nutrient availability, and accounting for bird sex variation. The authors found that increased pellet to fine ratios increased FI and LWG and had a more minor effect on decreasing FCR [9]. This type of research provides integrated poultry operations justification for investing in techniques that improve pellet quality. However, research must be conducted in a manner that best mimics industry conditions and reduces experimental error in order for results to properly guide the industry. Many research institutions utilize small pens of broiler chickens as experimental units that may affect the estimation of variance components and consequently the application of said research to an industry setting. Shim and Pesti [10] examined the statistical and economic implications of different combinations of birds per replicate, and replicates per treatment for poultry research through a Microsoft Excel workbook [10]. These authors demonstrated through a power analysis that more replications, rather than an increase in birds per pen, generated improved results [10]. Although an increase in replications may improve research results it may be less indicative of industry standards, where there are large numbers of birds competing for resources. A study done by Leone and Estévez [11] observed that a larger bird 
group size demonstrated increased aggression when birds had to compete for limited access to feed during a restricted access phase. This observation may be especially important in feed quality research. Based on past research and the goal of providing applicable data to the industry, the objective of this study was to compare the performance of straight run Hubbard $\mathrm{x}$ Cobb broiler chickens receiving a standard crumble/pellet percentage (50\%) vs a modestly improved crumble/pellet percentage (70\%), in experimental units of either a large pen (46 birds) or small pen (23 birds) with equal bird density $\left(0.06 \mathrm{~m}^{2} / \mathrm{bird}\right)$.

\section{Feed Manufacture}

All feed was manufactured at the West Virginia University pilot feed mill [12]. All diets were formulated to meet nutrient needs of the bird based on Agristat standards [14] and were corn and soybean meal based (Table 1). Samples were taken throughout the feed manufacturing process and analyzed for percentages of crude protein (Kjeldahl anlysis), crude fat (ether extract), calcium, ash and moisture (dry matter), then non-phytate phosphorus was calculated (Table 1). Diets were manufactured at approximately $82^{\circ} \mathrm{C}$, using a $38.1 \mathrm{x} 4.8 \mathrm{~mm}$ die with an average production rate of 1.02 tonne/h relative to the recommended mill capacity $(0.91$ tonne/h), and crumbled to a small particle, large particle or maintained as a pellet depending on growth phase $($ Table 2$)$. All dietary treatments $(70 \%$ crumble/pellet $=$ Improved vs. $50 \%$ crumble/pellet $=$ standard) were manufactured using similar techniques, to maintain nutrient availability, and feed form variation was produced by grinding a portion of the pelleted feed and remixing. The percentages of pellets, crumbles, and fines were determined by sifting a representative sample (50lb bag) through a number 5 and 14 U.S. sieve (Table 2). The two dietary treatments and resulting feed form characteristics are described in Table 2. 


\section{Growth Performance}

Forty six or 23 straight run Hubbard x Cobb 1-d-old chicks from a commercial hatchery [15] were randomly assigned to large $(1.2 \times .2 .4 \mathrm{~m})$ or small $(0.69 \times 2.4 \mathrm{~m})$ pens respectively at a density of $0.06 \mathrm{~m}^{2} / \mathrm{bird}$. A total of 1,300 broilers and 40 pens were utilized in the experiment. Floor pens containing fresh shavings were utilized within a cross-ventilated negative-pressure house. Feed and water were provided for ad libitum consumption. Each pen contained nipple drinkers (approximately 1 nipple to 12 birds) and feed pans that were adapted to hoppers. The temperature, lighting, and humidity schedules modeled that of a commercial integrator. One feed pan/hopper was placed in each small pen and two feed pan/hoppers were placed in each large pen. Feed pan space mimicked that of industry $\left(0.06 \mathrm{~m}^{2} / \mathrm{bird}\right)$ through placement of a laminated wood restrictor over top of the feed pan [16]. Feeder space was consistent with Choretime recommendations for small broilers [16]. Individual broiler weights were obtained at the end of each growth phase (d 1-10, d 11-21, and d 22-38) in order to measure growth performance variables [FI, LWG, FCR (adjusted for mortality), Table 3]. On d 38 either two or four male birds (small or large pens respectively) were selected $\pm 100 \mathrm{~g}$ of the mean bird body weight per pen for analysis of hot breast weight and yield. Birds were cared for according to West Virginia University Animal Care and Use Committee Guidelines.

\section{Statistical Analysis}

Performance variables were analyzed using a 2 (feed quality) x 2 (pen size) factorial arrangement of treatments in a randomized complete block design. The experimental unit was a pen of broilers. Prior to analysis of variance, Levene's test was performed to check homosedasticity, using the main effects and interaction means in three separate analyses. If variance was found to be heterogenous, then Friedman's Chi-Square test was utilized. The main effects of feed quality and pen size as well as their interaction were determined, and Fisher's 
LSD test was used for multiple comparisons. The statistical analysis was performed through the GLM or FREQ procedure of the Statistical Analysis System (SAS) [17]. Alpha was designated as 0.05 , and letter superscripts demonstrate differences among means. Alpha values between 0.1 and 0.05 were considered a trend towards a significant treatment effect. Although, feed phase data was collected and analyzed, only the overall period data has been presented and discussed.

\section{RESULTS AND DISCUSSION}

Manufacturing parameters and feed quality descriptors are presented in Table 2. Nutrient availability was maintained similar among both dietary treatments by manufacturing diets at the same time using consistent manufacturing techniques then generating crumble/pellet percentage differences through grinding and mixing. Percentage differences among treatments were developed in part to continue the work of Lilly et al [1]. Lilly [1] compared the effects of four different pellet-to-fine dietary treatments (90:10 high pellet quality, 60:40 medium pellet quality, 30:70 low pellet quality, and 0:100 ground pellet quality) on Cobb x Cobb broiler performance. They found that each 10-percentage-point increase in pellets; increased FI by 100-g, improved FCR by 0.4-points, and increased breast weight by 4-g [1]. In the current study, the improved pellet percentage treatment showed a trend to decrease FI $(P=0.07)$, maintained similar weight gain $(P=0.3)$, and demonstrated a trend towards decreased FCR by 3 -points $(P=0.1$, Table 3$)$. Intake differences between the two studies may be associated with variation in genetic strain and/or the decreased feeder space access of the current study. Regardless, these data show that a modest improvement in pellet quality may provide performance benefits. The coefficient of variation (CV) for bodyweight (Table 3) shows a significant effect for feed quality where an improved crumble/pellet percentage produced a higher within pen variation in body weight $(P=$ 0.05). This analysis was supported by Levene's test that found the variance to be heterogenous 
363 for live weight gain due to feed quality $(\mathrm{P}=0.006)$, demonstrating higher variability for the 364 improved pellet percentage treatment. Based on these data we speculate that the within pen 365 coefficient of variation for body weight may have been affected in part by the feeder space 366 access permitting the more dominant birds fed the improved pellet percentage treatment to 367 consume the majority of crumbles/pellets, leaving fines for the less dominant birds. Resources 368 located in one exclusive area may allow for dominant individuals to control access to those 369 resources forcing subordinates (weaker birds) to wait [11, 18-26]. These data are similar to that 370 shown by Shim and Pesti [10], where the authors demonstrated through a power analysis that 371 more replications, rather than an increase in birds per pen, generated improved results [10]. 372 These behavioral tendencies anecdotally were observed as a "follow the leader" effect where one 373 bird committing to one activity would in turn cause other birds to partake in the same activity; 374 such as consuming more feed from one hopper than another within a large pen. These results are 375 similar to those observed in a behavioral study completed by Leone and Estévez [11]. Leone and 376 Estévez observed more aggression in a larger bird group size when birds had to compete for 377 limited access to feed during a restricted access phase [11]. Previous research demonstrates that 378 phenotypic variance among experimental models increases when pushed to optimum or desired 379 performance [26-28]. We can speculate that although pelleting reduces ingredient segregation [13808 ], possible feed form segregation effects, due to the improved crumble/pellet percentage (70\%), 381 may have influenced performance variables. A small pen size (23 birds) demonstrated increased 382 LWG $(P=0.03)$. This observation may also be associated with behavioral tendencies that 383 created more stress in large pens. Table 3 shows that main effects did not interact for any 384 performance metric, suggesting that small pens of broilers are a sufficient experimental unit to 385 assess feed quality variation. 
1. Modest improvements in pellet quality ( $50 \%$ crumbles/pellets to $70 \%$ crumbles/pellets) may improve broiler performance (FI and FCR).

2. The within pen ending weight $\mathrm{CV}$ increased with increased feed quality likely due to dominant broilers monopolizing feeder space and consuming the majority of pellets.

3. Feed quality and pen size did not interact, demonstrating that small pens of broilers are a sufficient experimental unit to assess feed quality variation.

\section{REFERENCES AND NOTES}

1. Lily, K.G.S.; Gehring, C.K.; Beaman, K.R.; Turk, P.J.; Sperow, M.; and Moritz, J.S.(2011). Examing the relationships between Pellet Quality, Broiler Performance, and Bird Sex. J. Appl. Poult. Res., 20, 231-239.

2. Behnke, K. C. 1996. Feed manufacturing technology: Current issues and challenges. Anim. Feed Sci. Technol. 62:49-57.

3. Jensen, L. S., L. H. Merrill, C. V. Reddy, and J. Mc-Ginnis. 1962. Observations on eating patterns and rate of food passage of birds fed pelleted and unpelleted diets. Poult. Sci. 41:1414-1419.

4. Hott, J. M., N. P. Buchanan, S. E. Cutlip, and J. S. Moritz. 2008. The effect of moisture addition with a mold inhibitor on pellet quality, feed manufacture, and broiler performance. J. Appl. Poult. Res. 17:262-271.

5. Moritz, J. S., R. S. Beyer, K. J. Wilson, K. R. Cramer, L. J. McKinney, and F. J. Fairchild. 2001. Effect of moisture addition at the mixer to a corn-soybean based diet on broiler performance. J. Appl. Poult. Res. 10:347-353.

6. Nir, I., Y. Twina, E. Grossman, and Z. Nitsan. 1994. Quantitative effects of pelleting on performance, gastrointestinal tract and behavior of meat-type chickens. Br. Poult. Sci. 35:589-602.

7. Behnke, K. C. 1994. Factors affecting pellet quality. Pages 44-54 in Proc. Maryland Nutr. Conf., College Park, MD. Maryland Feed Ind. Counc. and Univ. Maryland, College Park.

8. Scheideler, S. E. 1991. Pelleting is important for broilers. Pages 1-7 in Proc. 18th Annu. Carolina Poult. Nutr. Conf., Charlotte, NC. North Carolina State Univ., Raleigh. 9. Lilly, K. G. S., C. K. Gehring, K. R. Beaman, P. J. Turk, M. Sperow, and J. S. Moritz. 2011. Examining the relationships between pellet quality, broiler performance, and bird sex. J. Appl. Poult. Res. 20: 231 - 239.

10. Shim, M.Y. and G.M. Pesti. 2014. The use of a pen size optimization workbook for experiment research design using the Visual Basic for Applications in Excel for poultry.J. Appl. Poult. Res. 23:315-322. 
11. Leone E.H. and I. Estévez. 2008. Environment, Well-Being, and Behavior: Space Use According to the Distribution of Resources and Level of Competition. J. Poultry Science 87:3-13.

12. Master Model Pellet Mill, California Pellet Mills Company, Crawfordsville, IN.

13. American Society for Agricultural Engineers. 1983. Methods for determining and expressing fineness of feed materials by sieving. Page 325 in American Society of Agricultural Engineers Standard S 319. Am. Soc. Agric. Eng. Yearbook Standards, Am. Soc. Am. Eng., St. Joseph, MI. Pellet durability index was determined by sifting $500 \mathrm{~g}$ of pellets from a treatment through a No. 6 American Society for Testing and Materials (ASTM) screen before being deposited into a Pfost tumbler. The sifted pellets were then tumbled in the container, dimensions $5 \times 12 \times 12$ in., with a $2 \times 9$ in. plate fixed diagonally along the $12 \times 12 \mathrm{in}$. side, for approximately $10 \mathrm{~min}$ at $50 \mathrm{rpm}$. The sample was then sifted again through the No. 6 (ASTM) mm screen, weighed, and the percentage of pellets was calculated by dividing the weight of pellets after tumbling by the weight of pellets before tumbling and then multiplying that value by 100 . Modified pellet durability index was similarly measured, with the exception of the addition of five, $13-\mathrm{mm}$ hexagonal bolts to the $500 \mathrm{~g}$ of sample in the tumbler. Both analyses are meant to simulate the deleterious effects of transferring and handling the pellets.

14. AgriStats Inc., Fort Wayne, IN; year 2013.

15. Pilgrims Pride Hatchery. Moorefield, WV

16. Model C2M, Chore-time/Brock International, Milford, IN.

17. SAS Institute. 2000. The SAS System for Windows 2000. Release 8.1. SAS Inst. Inc., Cary, NC.

18. King, M. G. 1965. Disruptions in the pecking order of cockerels concomitant with degrees of accessibility to feed. Anim. Behav. 13:504-506.

19. Banks, E. M. 1984. Relations between aggressive social dominance and resource utilization in domestic fowl. Polit. Psychol. 5:617-622.

20. Caraco, T., C. Barkan, J. L. Beacham, L. Brisbin, S. Lima, A. Mohan, J. A. Newman, W. Webb, and M. L. Withiam. 1989. Dominance and social foraging: A laboratory study. Anim. Behav. 38:41-58.

21. Keeling, L. 1995. Spacing behavior and an ethological approach to assessing optimum space allocations for groups of laying hens. Appl. Anim. Behav. Sci. 44:171186.

22. Pagel, M., and M. S. Dawkins. 1997. Peck orders and group size in laying hens: 'Futures contracts' for non-aggression. Behav. Process. 40:13-25.

23. Stahl, J., P. H. Tolsma, M. J. J. E. Loonen, and R. H. Drent. 2001. Subordinates explore but dominants profit: Resource competition in high Arctic barnacle goose flocks. Anim. Behav. 61:257-264.

24. Dubois, F., L. A. Giraldeau, and J. W. A. Grant. 2003. Resource defense in a group-foraging context. Behav. Ecol. 14:2-9. 
472

72

25. Banks, E. M., D. G. M. Wood-Gush, B. O. Hughes, and N. J.Mankovich. 1979. Social rank and priority of access to resources in domestic fowl. Behav. Proc. 4:197209.

26. 14. Mulder HA, Bijma P, Hill WG. Prediction of breeding values and selection responses with genetic heterogeneity of environmental variance. Genetics. 2007; 175:1895-1910.

27. Hill WG. On selection among groups with heterogeneous variance. Anim Prod. 1984;39:473-477.

28. Hill WG, Zhang X-S. Effects on phenotypic variability of directional selection arising through genetic differences in residual variability. Genet Res. 2004;83:121-131. 
473 Table 1. Diet formulations ${ }^{1}$ and nutrient specifications

\begin{tabular}{|c|c|c|c|}
\hline Item & $\begin{array}{c}\text { Starter diet } \\
(1 \text { to } 10 \text { d })\end{array}$ & $\begin{array}{l}\text { Grower diet } \\
(11 \text { to } 21 \text { d) } \\
\end{array}$ & $\begin{array}{c}\text { Finisher diet } \\
\text { (22 to } 38 \text { d })\end{array}$ \\
\hline \multicolumn{4}{|l|}{ Ingredient \% } \\
\hline Corn & 58.86 & 61.62 & 68.17 \\
\hline Soybean Meal (48\%) & 31.18 & 26.31 & 20.23 \\
\hline Meat and Bone Meal (50\%) & 5.00 & 5.00 & 5.00 \\
\hline Animal and Vegetable Blend Fat & 3.49 & 3.61 & 3.42 \\
\hline Dicalcium Phosphate & 1.54 & 1.31 & 1.29 \\
\hline Limestone & 0.74 & & \\
\hline Salt & 0.30 & 0.66 & 0.65 \\
\hline DL Methionine & 0.32 & 0.35 & 0.32 \\
\hline Poultry Premix ${ }^{4}$ & 0.25 & 0.31 & 0.22 \\
\hline Lysine & 0.21 & 0.25 & 0.25 \\
\hline Threonine & 0.09 & 0.18 & 0.17 \\
\hline Chloromax $50^{5}$ & 0.03 & 0.28 & 0.26 \\
\hline BMD $60^{6}$ & - & - & 0.03 \\
\hline Coban $90^{7}$ & - & 0.08 & - \\
\hline \multicolumn{4}{|l|}{ Calculated Nutrients } \\
\hline $\mathrm{ME}, \mathrm{kcal} / \mathrm{kg}$ & 1386.0 & 1409.0 & 1434.0 \\
\hline Crude Protein & 22.40 & 20.60 & 18.09 \\
\hline Methionine, $\%$ & 0.88 & 0.83 & 0.69 \\
\hline Lysine, $\%$ & 1.19 & 1.05 & 0.90 \\
\hline Calcium, \% & 1.15 & 1.06 & 1.04 \\
\hline Available Phosphorus, \% & 0.60 & 0.55 & 0.54 \\
\hline \multicolumn{4}{|l|}{ Analyzed Nutrients ${ }^{8}$} \\
\hline Moisture & 16.83 & 14.90 & 12.84 \\
\hline Crude Protein & 20.52 & 18.89 & 17.66 \\
\hline Crude Fat & 5.87 & 6.09 & 5.98 \\
\hline Ash & 5.65 & 5.37 & 4.84 \\
\hline Calcium $^{9}$ & 1.30 & 1.08 & 1.14 \\
\hline $\mathrm{Npp}^{10}$ & 0.56 & 0.48 & 0.48 \\
\hline \multicolumn{4}{|c|}{ 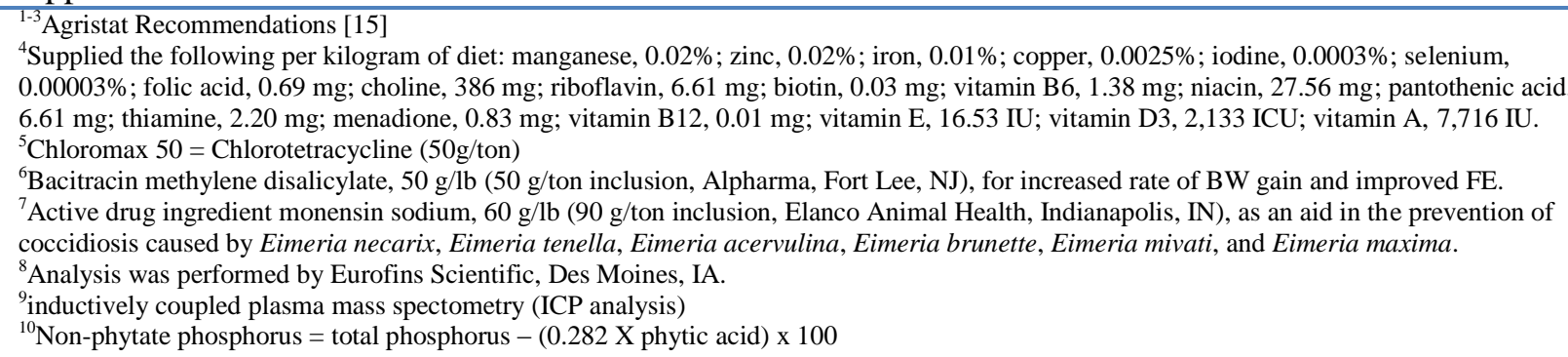 } \\
\hline
\end{tabular}


Table 2. Manufacturing variables and pellet quality for growth periods

\begin{tabular}{|c|c|c|c|}
\hline Item & $\begin{array}{l}\text { Starter diet } \\
(1 \text { to } 10 \text { d })\end{array}$ & $\begin{array}{l}\text { Grower diet } \\
\text { (11 to } 21 \text { d) }\end{array}$ & $\begin{array}{c}\text { Finisher diet } \\
\text { (22 to } 38 \text { d) }\end{array}$ \\
\hline Die Size, mm x mm & $38.1 \times 4.8$ & $38.1 \times 4.8$ & $38.1 \times 4.8$ \\
\hline Production Rate, tonne/h (tons/h) & 1.02 & 1.16 & 1.31 \\
\hline Pellet Durability Index ${ }^{1}, \%$ & 84.4 & 86.4 & 86.6 \\
\hline Modified Pellet Durability Index ${ }^{2}, \%$ & 78.6 & 81.5 & 81.2 \\
\hline $\mathrm{NHP}^{3}, \%$ & 80.1 & 79.2 & 76.0 \\
\hline Treatment & $\begin{array}{l}\text { Standard vs } \\
\text { Improved }\end{array}$ & $\begin{array}{c}\text { Standard vs } \\
\text { Improved }\end{array}$ & $\begin{array}{l}\text { Standard vs } \\
\text { Improved }\end{array}$ \\
\hline Pellet $^{5}, \%$ & 0 vs. 0 & 12 vs. 32 & 54 vs. 69 \\
\hline Crumble $^{6}, \%$ & 51 vs. 71 & 47 vs. 52 & 21 vs. 17 \\
\hline Fine $^{7}, \%$ & 49 vs. 29 & 41 vs. 16 & 25 vs. 14 \\
\hline Bulk Density Pellets ${ }^{8}\left(\mathrm{~kg} / \mathrm{m}^{3}\right)$ & 674 vs. 578 & 732 vs. 622 & 753 vs. 727 \\
\hline
\end{tabular}

${ }^{1}$ Pellet durability index was determined by placing $500 \mathrm{~g}$ of sifted pellets into a Pfost tumbler. Samples were tumbled for $10 \mathrm{~min}$ at $50 \mathrm{rpm}$. The sample was then sifted again and weighed. Pellet durability index was calculated as the percentage of sifted pellets retained after tumbling (descriptive data).

${ }^{2}$ Modified pellet durability index was measured similarly to the previous description, with the exception that five 13-mm hexagonal nuts were added to the 500-g sample before tumbling (descriptive data).

${ }^{3}$ New Holman Pellet Test was determined by placing a $100 \mathrm{~g}$ of sifted pellets into the NHP. Samples were run for 30 seconds. The sample was then weighed and pellet durability was calculated as a percentage (descriptive data).

${ }^{5}$ Feed retained on a no. 6 ASTM screen $(4.0 \mathrm{~mm})$ was described as a pellet (descriptive data).

${ }^{6}$ Feed retained on a no. 14 ASTM screen $(1.4 \mathrm{~mm})$ was described as a crumble (descriptive data).

${ }^{7}$ Feed that passed through the no. 14 ASTM screen was described as fines (descriptive data).

${ }^{8}$ Bulk density is measured in $\mathrm{kg} / \mathrm{m} 3$ and was calculated from a $22.7-\mathrm{kg}$ sample of feed from each treatment replicate obtained from a complete feed sample. A box measuring $30.5 \times 30.5 \times 30.5 \mathrm{~cm}$ was then tared. Next, the feed sample was poured into the box reaching maximum capacity and the top was leveled off. The weight of the amount of feed that exactly filled the box was used to determine the bulk density (descriptive data). 


\begin{tabular}{|c|c|c|c|c|c|c|}
\hline Item & $\begin{array}{c}\text { FI }^{1} \text { per } \\
\text { Bird } \\
(\mathbf{k g})\end{array}$ & $\begin{array}{c}\mathbf{L W G}^{2} \\
(\mathbf{k g})\end{array}$ & $\begin{array}{c}\text { FCR }^{3} \\
(\mathrm{~kg} / \mathrm{kg})\end{array}$ & $\begin{array}{l}\text { CV }^{4} \\
\text { Among } \\
\text { Bird } \\
\text { Weight } \\
\text { Within } \\
\text { Pen }\end{array}$ & $\begin{array}{c}\text { Average } \\
\text { Bird } \\
\text { Breast } \\
\text { Weight } \\
\text { (kg) }\end{array}$ & $\begin{array}{c}\text { Average } \\
\text { Bird } \\
\text { Breast } \\
\text { Yield } \\
\text { (g/kg) }\end{array}$ \\
\hline \multicolumn{7}{|l|}{ Treatment } \\
\hline Standard Quality/Small Pen & 3.88 & 2.37 & 1.73 & 9.45 & 0.490 & 201.11 \\
\hline Standard Quality/Large Pen & 3.92 & 2.36 & 1.74 & 10.84 & 0.492 & 204.47 \\
\hline Improved Quality/Small Pen & 3.76 & 2.37 & 1.70 & 11.40 & 0.493 & 200.93 \\
\hline Improved Quality/Large Pen & 3.78 & 2.32 & 1.71 & 12.22 & 0.484 & 200.96 \\
\hline ANOVA $P$ value & 0.2039 & 0.1391 & 0.3662 & 0.1328 & 0.8978 & 0.8238 \\
\hline SEM $^{5}$ & 0.0600 & 0.0190 & 0.0157 & 0.8206 & 0.0093 & 3.1558 \\
\hline \multicolumn{7}{|c|}{ Marginal Means Based On Feed Quality } \\
\hline Standard Quality & 3.90 & 2.36 & 1.74 & 10.14 & 0.491 & 202.79 \\
\hline Improved Quality & 3.78 & 2.35 & 1.71 & 11.81 & 0.490 & 200.95 \\
\hline \multicolumn{7}{|c|}{ Marginal Means Based On Pen Size } \\
\hline Small Pen & 3.82 & 2.37 & 1.72 & 10.42 & 0.492 & 201.03 \\
\hline Large Pen & 3.85 & 2.34 & 1.73 & 11.53 & 0.488 & 202.72 \\
\hline \multicolumn{7}{|c|}{ Main Effect and Interaction P-values } \\
\hline Feed Quality $^{6}$ & 0.0659 & 0.3378 & 0.1042 & 0.0515 & 0.8239 & 0.5717 \\
\hline Pen Size ${ }^{7}$ & 0.6771 & $0.0570^{8}$ & 0.4192 & 0.1867 & 0.6785 & 0.6041 \\
\hline Feed Quality x Pen Size & 0.9190 & 0.3081 & 0.8711 & 0.7379 & 0.5855 & 0.6108 \\
\hline $\begin{array}{l}{ }^{1} \mathrm{FI}=\text { Feed Intake } \\
{ }^{2} \mathrm{LWG}=\text { Live Weight Gain } \\
{ }^{3} \mathrm{FCR}=\text { Feed Conversion Ratio } \\
{ }^{4} \mathrm{CV}=\text { Coefficient of Variation } \\
{ }^{5} \mathrm{SEM}=\text { Standard Error of the Mean } \\
{ }^{6} \mathrm{Feed} \text { Quality }=\text { Standard Quality }(50 \% \text { Pell } \\
{ }^{7} \mathrm{Pen} \text { Size }=\text { Small Pen }(0.69 \times 2.44 \mathrm{~m}) \text {, or L } \\
{ }^{8} \text { The variance was found to be heterogenous } \\
\text { Friedman's Chi-Square Test, and the pen siz }\end{array}$ & $\begin{array}{l}\text { oved Quality } \\
(1.2 \times 2.44 \mathrm{~m} \\
\text { weight gain } \\
\text { ffect for live }\end{array}$ & $\begin{array}{l}\% \text { Pellets) } \\
\text { feed quali } \\
\text { ht gain was }\end{array}$ & to be sig & $(\mathrm{P}=0.0$ & $x_{10}$ & REQ \\
\hline
\end{tabular}


513 CHAPTER 3: MANUSCRIPT PREPARED FOR JOURNAL OF APPLIED POULTRY

514 RESEARCH: THE EFFECTS OF MODEST IMPROVEMENT TO PELLET QUALITY

515 ON TOM TURKEY PERFORMANCE

516

517

B.G. Glover*, A.M. Evans, and J.S. Moritz*1

518

519

520

521

522

523

524

525

Metabolism and Nutrition

526

527

*Department of Animal and Nutritional Sciences, Davis College of Agriculture, Natural Resources and Design, West Virginia University, Morgantown, WV 26506

Metabolism and Nutrition

528

529

530

531

$532 \quad{ }^{1}$ Corresponding Author: Joe.Moritz@mail.wvu.edu

533 Primary Audience: Researchers, Nutritionists, Feed Mill Managers

534 
SUMMARY: Feed and feed manufacture consists of $60-70 \%$ of turkey production cost.

Past research has demonstrated that benefits of pelleting per se ultimately provide an economic return on investment. However, less is understood concerning returns on modest improvements to feed of poor physical quality. The objective of this study was to compare the performance of tom turkeys that receive feed of standard physical quality at the feed pan to tom turkeys receiving an improved pellet percentage at the feed pan. A common starter diet was batched, mixed, steam conditioned at $79^{\circ} \mathrm{C}$, extruded through a 44.5 by $4.8 \mathrm{~mm}$ pellet die, and crumbled at the West Virginia University pilot feed mill. Physical feed quality differences of the starter diet were created by manipulating the roller mill gap during the crumbling process. The physical quality of the starter diets was defined as retained percentage of sieved feed and particle size. Feed retained on a no. 5 ASTM screen $(4.0 \mathrm{~mm})$ was described as a pellet, feed retained on a no. 14 ASTM screen $(1.4 \mathrm{~mm})$ was described as a crumble, and feed that passed through the no. 14 ASTM screen was described as fines. The feed for the remaining growth phases ( 2 growers, and 2 finishers) was manufactured at a commercial feed mill. The standard pellet quality diet for the grower and finisher phases were ground to contain an average percentage of pellets (40\%) vs. that of the improved pellet quality diet (70\%). Diets were fed to 8 replicate pens of 80 Hybrid Converter male poults using a randomized complete block design. Average pen weight significantly increased for toms fed improved quality pellets by $0.17 \mathrm{~kg}(P=0.02)$ and tended to decrease feed conversion ratio by 11 -points $(P=0.07)$ compared to toms fed standard quality pellets. These data suggest that improvements in crumble/pellet percentage may provide growth performance benefits.

Keywords: pellet, turkey, feed form, particle size, crumble 

provide an economic return on investment. These benefits include: increased live weight gain

561 (LWG), decreased feed conversion ratio (FCR), decreased pathogens in feed, decreased 562 ingredient selection, and improved feed flow [1-9]. Performance differences have been 563 numerically greater for turkeys than broilers, possibly due to the increased grow out time and 564 consistent exposure to pelleted feed. Commercial feed mills typically maintain a high through565 put of feed pelleting to keep up with bird feeding requirements. Consequently feed quality is 566 poor due to decreased residence time of conditional mash in the pellet die. One solution to 567 resolve poor pellet quality is through the incorporation of a pellet binder such as calcium 568 lignosulfonate (CaLS) into a diet formulation. Corey and coauthors [10] showed that the 569 inclusion of CaLS binder $(0.5 \%)$ increased both the pellet and modified pellet durability index (P $570<0.05)[10]$. These authors also observed that CaLS decreased pellet mill motor amperage and 571 pellet temperature after die extrusion $(\mathrm{P}<0.01)[10]$. These findings show potential to improve 572 pellet quality and maintain through-put demands. Much of past research that has focused on 573 pellet quality incorporates treatment extremes such as a 90:10 pellet to fine percentage in 574 comparison to a 0:100 pellet to fine percentage [1]. High pellet quality such as 90:10 pellet to 575 fine percentage has been argued to be impossible to obtain in the commercial industry due to 576 throughput demands, but also due to the magnitude of transportation and auguring stress that 577 pellets endure. A need exists to explore the effect of modest improvement in pellet quality 578 obtained through techniques practical for the commercial industry. The objective of this study 579 was to assess the effect of improving pellet quality from $40 \%$ pellets to $70 \%$ pellets through use 580 of CaLS and decreased pellet production rate on 1-126 d tom turkey performance. 


\section{MATERIALS AND METHODS}

582

583

584 585 586 587 588 589 590 591 592

\section{Feed Manufacture}

The starter diets for this experiment were manufactured at the West Virginia University pilot feed mill [11] using CaLS as a pellet binder at a $0.5 \%$ inclusion. The grower and finisher diets were manufactured by a commercial feed mill. All diets were formulated to meet nutrient needs of the bird based on commercial standards and were corn and soybean meal based (Table 1). The manufacturing technique for the starter diets were accomplished by creating four 907.4$\mathrm{kg}$ basal batches. Fat inclusion consisted of 4\% pre-pellet mixer-added fat (MAF) and 3.5\% fat added post pellet. Each batch was pelleted using a 40HP California pellet mill [11] equipped with a thick pellet die $(4.8 \times 45 \mathrm{~mm})$ at a conditioning temperature of $82^{\circ} \mathrm{C}$. A representative sample was collected from the pellet cool deck for pellet durability index (PDI) and modified pellet durability index (MPDI) (Table 1) [13]. Grower and finisher diets were manufactured using a $400 \mathrm{HP}$ California Pellet Mill [11] at approximately $82^{\circ} \mathrm{C}$, with an average production rate of 40 tonne/hour relative to the maximum production rate (60 tonne/hour), necessitating a $30 \%$ drop in production rate. All dietary treatments $(70 \%$ crumble/pellet $=$ Improved vs. $40 \%$ crumble/pellet $=$ standard) were manufactured maintaining nutrient variability by grinding a portion of the improved treatment in order to produce the standard treatment. The two dietary treatments and resulting feed form characteristics are described in Table 2. Diet nutrient analysis included percent non-phytate phosphorus (nPP), calculated by taking the total phytate times 0.282 and then subtracting that value from the total phosphorus [12] and protein, fat, and calcium percentage [14].

\section{Growth performance}

Eighty Hybrid Converter male 1-d-old poults were randomly assigned to pens $(6 \times 5 \mathrm{~m})$ at a density of $0.39 \mathrm{~m}^{2} / \mathrm{bird}$, at the West Virginia University turkey facility located in Wardensville, 
605 WV [15]. A total of 1,280 male turkeys and 16 pens were utilized in the experiment. Floor pens 606 containing fresh shavings were utilized within a tunnel-ventilated house. Feed and water were 607 provided for ad libitum consumption. The temperature, lighting, and humidity schedules 608 mimicked that of a commercial integrator. Individual weigh scales were placed within each pen 609 to record weekly bird weights. Individual bird weigh days were designated at the end of each 610 growth phase: starter (d 1-42), grower (d 42-91), and finisher (d 91-126) in order to measure 611 growth performance variables [FI, LWG, FCR (adjusted for mortality), Table 3]. The starter feed 612 was hand fed to each pen, and the grower and finisher periods utilized an automated feed 613 conveyance and weigh system. On day 126, tom turkeys were weighed by pen and transported to 614 a commercial processing facility. A total of 50 toms were randomly selected per treatment and 615 utilized for descriptive carcass evaluation (Table 4).

\section{$616 \quad$ Statistical Analysis}

617 A pen of turkeys represented the experimental unit. Treatments were analyzed as a 618 randomized complete block design, with birds fed one of two dietary treatments (standard pellet 619 quality or improved pellet quality). A one-way ANOVA test was performed to compare the 620 means of each treatment. Statistical analysis and data tables were produced through the GLM 621 procedure of SAS [16]. Alpha was set at a p-value less than or equal to 0.05, and letter 622 superscripts were utilized to symbolize differences among treatment means.

\section{RESULTS AND DISCUSSION}

625 in Table 2. Nutrient availability was maintained similar among both dietary treatments by 626 manufacturing diets using consistent manufacturing techniques then generating crumble/pellet 627 percentage differences through grinding a portion of the feed $(40 \%$ crumble/pellet $=$ standard, 
$62870 \%$ crumble/pellet $=$ improved). The pilot mill utilized $0.5 \%$ CaLS and the commercial feed 629 mill manufactured the improved pellet treatment through a $30 \%$ reduction to production rate and 630 the inclusion of CaLS at $0.5 \%$. Previous research has shown that the inclusion of a pellet binder 631 (CaLS) improves pellet quality [10]. Pelleting differences consisted of an average crumble/pellet 632 difference of $30 \%, 1,571.6$ microns particle size, and pellet durability on average differed by $63365 \%$ (Table 2). Percentage differences were developed in part to continue the work of previous 634 research done by Wamsley [19]. Wamsley [19] through a regression analysis predicted that if 635 toms fed a ground pellet diet finished at the same weight (d 118) as those fed a high quality 636 pellet diet, then FCR advantages of high quality pellet would be 12 points [19]. These authors 637 also reported that toms fed a high quality pellet from $42-118 \mathrm{~d}$ grew $0.29 \mathrm{~kg}$ heavier than birds 638 fed a ground pellet diet [19]. In the current study, the improved crumble/pellet percentage (70\%) 639 was defined as the average of the starter, grower, and finisher calculated percentage of pellets. 640 This demonstrated a trend for an 11 point improvement in FCR $(P=0.07)$, along with a 641 significant improvement to tom turkey gain of $0.17 \mathrm{~kg}(P=0.02$, Table 3$)$. Research focusing on 642 pelleting effects on turkey performance are sparse; however a previous study done by Lilly et al 643 [1] demonstrated that each 10-percentage-point increase in pellets; increased FI by 100-g, 644 improved FCR by 0.4-points, and increased breast weight by 4-g in Cobb 500 broilers $[1,17]$. 645 This is similar to the results reported in a study conducted by Proudfoot and Hulan [18]; which 646 demonstrated that pelleted finisher diets had a significant improvement on both 98-day female 647 turkey body weight and overall FCR, concluding that the higher levels of fines had a significant 648 detrimental effect on FCR [18]. In the current study, no descriptive carcass data demonstrated 649 that feeding an improved crumble/pellet percentage numerically increased breast weight 650 compared to birds fed a standard crumble/pellet percentage (Table 4). These data and past 
research continue to support that the use of a pellet binder and reduced pellet production rate can improve pellet quality, and feeding these improved pellet percentages can improve growth performance in meat birds.

\section{CONCLUSIONS AND APPLICATIONS}

1. A commercial feed mill was able to produce a $70 \%$ pellet to turkeys using a $0.5 \%$ CaLS diet formulation and a $30 \%$ reduction in normal pellet production rate.

2. Feeding improved quality pellets $70 \%$ pellets compared to $40 \%$ pellets improved tom turkey gain by $0.17 \mathrm{~kg}(P=0.02)$ and tended to decrease FCR by 11 points $(P=0.07)$.

\section{REFERENCES AND NOTES}

1. Lily, K.G.S.; Gehring, C.K.; Beaman, K.R.; Turk, P.J.; Sperow, M.; and Moritz, J.S.(2011). Examing the relationships between Pellet Quality, Broiler Performance, and Bird Sex. J. Appl. Poult. Res., 20, 231-239.

2. Behnke, K. C. 1996. Feed manufacturing technology: Current issues and challenges. Anim. Feed Sci. Technol. 62:49-57.

3. Jensen, L. S., L. H. Merrill, C. V. Reddy, and J. Mc-Ginnis. 1962. Observations on eating patterns and rate of food passage of birds fed pelleted and unpelleted diets. Poult. Sci. 41:1414-1419.

4. Hott, J. M., N. P. Buchanan, S. E. Cutlip, and J. S. Moritz. 2008. The effect of moisture addition with a mold inhibitor on pellet quality, feed manufacture, and broiler performance. J. Appl. Poult. Res. 17:262-271.

5. Moritz, J. S., R. S. Beyer, K. J. Wilson, K. R. Cramer, L. J. McKinney, and F. J. Fairchild. 2001. Effect of moisture addition at the mixer to a corn-soybean based diet on broiler performance. J. Appl. Poult. Res. 10:347-353.

6. Nir, I., Y. Twina, E. Grossman, and Z. Nitsan. 1994. Quantitative effects of pelleting on performance, gastrointestinal tract and behavior of meat-type chickens. Br. Poult. Sci. 35:589-602.

7. Behnke, K. C. 1994. Factors affecting pellet quality. Pages 44-54 in Proc. Maryland Nutr. Conf., College Park, MD. Maryland Feed Ind. Counc. and Univ. Maryland, College Park.

8. Scheideler, S. E. 1991. Pelleting is important for broilers. Pages 1-7 in Proc. 18th Annu. Carolina Poult. Nutr. Conf., Charlotte, NC. North Carolina State Univ., Raleigh.

9. Lilly, K. G. S., C. K. Gehring, K. R. Beaman, P. J. Turk, M. Sperow, and J. S. Moritz. 2011. Examining the relationships between pellet quality, broiler performance, and bird sex. J. Appl. Poult. Res. 20: $231-239$. 
10. A.M. Corey, K.G.S. Wamsley, T.S. Winowiski, and J.S. Moritz. 2014. Effects of calcium lignosulfinate, mixer-added fat, and feed form on feed manufacture and broiler performance. J. Appl. Poult. Res. 23:418-428.

11. Master Model Pellet Mill, California Pellet Mills Company, Crawfordsville, IN. 12. $\mathrm{nPP}=$ Total Phosphorus $-($ Total Phytate $\mathrm{X} 0.282)$

13. American Society for Agricultural Engineers. 1983. Methods for determining and expressing fineness of feed materials by sieving. Page 325 in American Society of Agricultural Engineers Standard S 319. Am. Soc. Agric. Eng. Yearbook Standards, Am. Soc. Am. Eng., St. Joseph, MI. Pellet durability index was determined by sifting $500 \mathrm{~g}$ of pellets from a treatment through a No. 6 American Society for Testing and Materials (ASTM) screen before being deposited into a Pfost tumbler. The sifted pellets were then tumbled in the container, dimensions $5 \times 12 \times 12$ in., with a $2 \times 9$ in. plate fixed diagonally along the $12 \times 12 \mathrm{in}$. side, for approximately $10 \mathrm{~min}$ at $50 \mathrm{rpm}$. The sample was then sifted again through the No. 6 (ASTM) mm screen, weighed, and the percentage of pellets was calculated by dividing the weight of pellets after tumbling by the weight of pellets before tumbling and then multiplying that value by 100 . Modified pellet durability index was similarly measured, with the exception of the addition of five, 13-mm hexagonal bolts to the $500 \mathrm{~g}$ of sample in the tumbler. Both analyses are meant to simulate the deleterious effects of transferring and handling the pellets.

14. Eurofins Scientific, Des Moines, IA.

15. Turkey grow-out facility, Wardensville, WV.

16. SAS Institute. 2000. The SAS System for Windows 2000. Release 8.1. SAS Inst. Inc., Cary, NC.

17. Cobb-Vantress, Siloam Springs, AR. 2008.

18. Proudfoot, F. G., and H. W. Hulan. 1982. Feed texture effects on the performance of turkey broilers. Poult. Sci.61:327-330.

19. Wamsley, K.G.S. 2012. Strategies to maximize feed quality and poultry performance. Dissertation published by West Virginia University. 


\begin{tabular}{|c|c|}
\hline Item & $\begin{array}{l}\text { Starter diet } \\
(1 \text { to } 42 \text { d) }\end{array}$ \\
\hline \multicolumn{2}{|l|}{ Ingredient \% } \\
\hline Corn & 35.60 \\
\hline Soybean Meal(48\%) & 41.95 \\
\hline Poultry Meal & 10.00 \\
\hline Animal and Vegetable Blend Fat & 7.50 \\
\hline Dicalcium Phosphate (18.5\%) & 1.80 \\
\hline Limestone & 1.20 \\
\hline Salt & 0.105 \\
\hline Sodium Bicarbonate & 0.075 \\
\hline DL Methionine & 0.365 \\
\hline Lysine & 0.215 \\
\hline Threonine & 0.055 \\
\hline VPGC Turkey Starter & 0.15 \\
\hline Choline Chloride (60\%) & 0.15 \\
\hline Copper Sulfate (25.2\%) & 0.05 \\
\hline AXTRA PHY $10000 \mathrm{~L}$ & 0.005 \\
\hline ROVABIO EXCEL LC2 & 0.011 \\
\hline Diamond V & 0.125 \\
\hline Prem Micro-Aid Premix & 0.10 \\
\hline Ameribond $2 X^{2}$ & 0.50 \\
\hline $\operatorname{Coban}^{3} 60$ & 0.04 \\
\hline $\mathrm{BMD}^{4} 50$ & 0.05 \\
\hline \multicolumn{2}{|l|}{ Calculated Nutrients } \\
\hline $\mathrm{ME}, \mathrm{kcal} / \mathrm{lb}$ & 1474.0 \\
\hline Methionine, $\%$ & 0.80 \\
\hline Lysine, \% & 1.85 \\
\hline Calcium, \% & 1.49 \\
\hline Non-Phytate Phosphorus, \% & 0.76 \\
\hline \multicolumn{2}{|l|}{ Analyzed Nutrients } \\
\hline Crude Protein $(\%)$ & 28.71 \\
\hline Crude Fat $(\%)$ & 9.69 \\
\hline Calcium (\%) & 1.57 \\
\hline Non-Phytate Phosphorus (\%) & 0.72 \\
\hline
\end{tabular}

${ }^{1}$ Agristat Recommendations [15]

${ }^{2}$ CaLS Binder at $0.5 \%$ inclusion

${ }^{3}$ Bacitracin methylene disalicylate, $50 \mathrm{~g} / \mathrm{lb}(50 \mathrm{~g} /$ ton inclusion, Alpharma, Fort Lee, NJ), for increased rate of BW gain and improved FE.

$718{ }^{4}$ Active drug ingredient monensin sodium, $60 \mathrm{~g} / \mathrm{lb}(90 \mathrm{~g} / \mathrm{ton}$ inclusion, Elanco Animal Health, Indianapolis, IN), as an aid in the prevention of 
Table 2: Descriptive feed quality of diets fed to tom turkeys from d 1-126.

\begin{tabular}{|c|c|c|}
\hline Item & Particle Size $^{1}$ (microns) & Percent Pellets $^{3}(\%)$ \\
\hline \multicolumn{3}{|l|}{ Diet $^{4}$} \\
\hline Prestart & 1,196 & 0.40 \\
\hline Starter $\left(\mathbf{S Q}^{5}\right)$ & 1,907 & 20.5 \\
\hline Starter $\left(I Q^{6}\right)$ & 2,521 & 62.6 \\
\hline Grower 1(SQ) & 2,923 & 40.1 \\
\hline Grower 1(IQ) & 4,515 & 79.7 \\
\hline Grower 2(SQ) & 2,787 & 37.1 \\
\hline Grower 2(IQ) & 4,226 & 67.0 \\
\hline Finisher 1(SQ) & 2,088 & 36.0 \\
\hline Finisher 1(IQ) & 4,479 & 67.2 \\
\hline Finisher 2(SQ) & 2,669 & 39.2 \\
\hline Finisher 2(IQ) & 4,164 & 68.4 \\
\hline \multicolumn{3}{|c|}{ 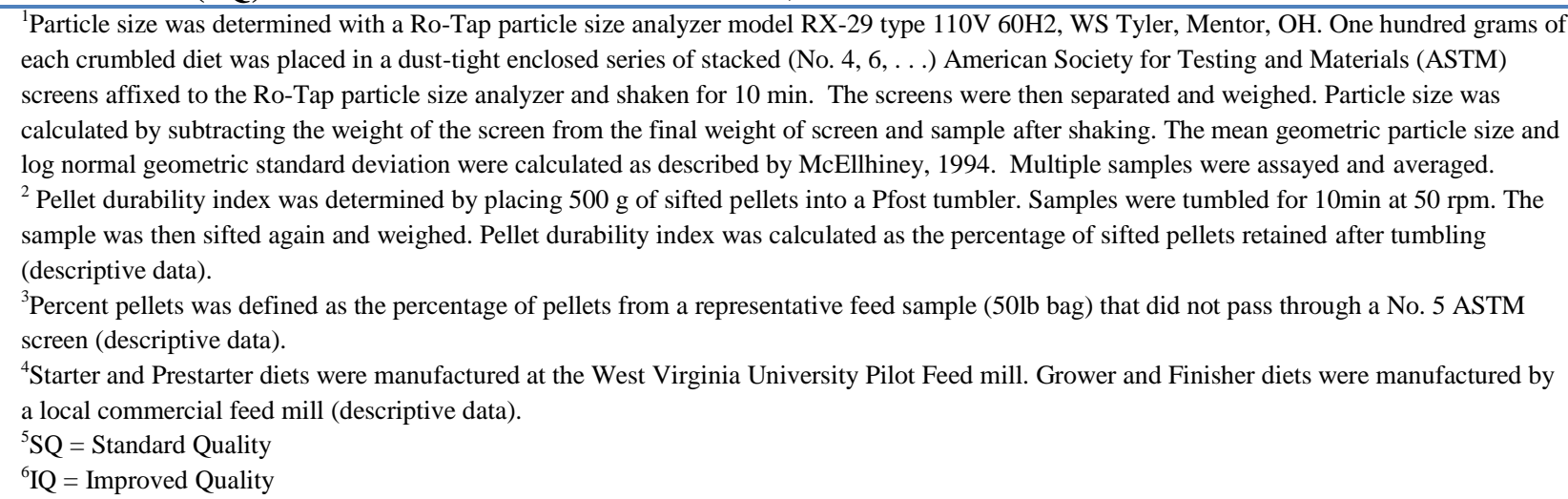 } \\
\hline
\end{tabular}


737 Table 3: Effect of feed quality (standard vs. improved) on tom turkey performance from d 738 1-126.

\begin{tabular}{lcccc}
\hline Item & $\begin{array}{c}\text { FI per Pen } \\
(\mathbf{k g})\end{array}$ & $\begin{array}{c}\text { Individual Tom } \\
\text { Weight Gain }(\mathbf{k g})\end{array}$ & FCR $^{\mathbf{2}}(\mathbf{k g : k g )}$ & Mortality (\%) \\
\hline Standard Quality & $3,237.32$ & 18.03 & 2.42 & 7.083 \\
Improved Quality & $3,235.61$ & 18.20 & 2.31 & 10.625 \\
ANOVA P-value & 0.9921 & 0.0173 & 0.0728 & 0.576 \\
SEM $^{3}$ & 26.93 & 0.1670 & 0.0291 & 1.983 \\
\hline
\end{tabular}

$739 \quad{ }^{1} \mathrm{FI}=$ Feed Intake

$740 \quad{ }^{2} \mathrm{FCR}=$ Feed Conversion Ratio

741 Standard Error of the Mean $(\mathrm{n}=8)$ 
743 Table 4: Descriptive processing plant data for d 1-126 tom turkeys.

\begin{tabular}{|c|c|c|c|}
\hline Item & $\begin{array}{l}\text { Average Canner } \\
\text { Weight (kg) }\end{array}$ & $\begin{array}{c}\text { Average Breast } \\
\text { Weight }(\mathbf{k g})\end{array}$ & $\begin{array}{c}\text { Average Breast } \\
\text { Yield }(\%)\end{array}$ \\
\hline Standard Quality & 15.61 & 3.52 & 22.524 \\
\hline Improved Quality & 15.80 & 3.61 & 22.846 \\
\hline
\end{tabular}




\section{Curriculum Vitae}

\section{Brian G. Glover, Master's Candidate}

• 1343 Headlee Ave. Apt. 13 Morgantown, WV 26505 • bglover2@mix.wvu.edu · (304)668-2558

Enthusiastic and works well within a team, but also proficient working as an individual. Not foreign to hard-work and thrives under pressure.

\section{PUBLICATIONS}

\section{First Author Publications:}

\section{Peer-reviewed manuscripts}

B.G. Glover, A.M. Evans, and J.S. Moritz. In association with VPGC. The effects of modest improvement to pellet quality on tom turkey performance. Journal of Applied Poultry Research. (In Preparation)

B.G. Glover and J.S. Moritz. Effects Of Modest Improvements In Pellet Quality And Experiment Pen Size On Broiler Chicken Performance. Journal of Applied Poultry Research. (In Preparation)

\section{Abstracts}

B.G. Glover and J.S. Moritz. 2015. Effects of modest improvements in pellet quality and experiment pen size on broiler chicken performance. Poultry Sci. (Accepted)

B.G. Glover, A.M. Evans, and J.S. Moritz. 2014. The effects of modest improvement to pellet quality on tom turkey performance. Poultry Sci. Vol. 95 (Suppl. 1): 65.

\section{Co-author Publications:}

\section{Peer-reviewed manuscripts}

A.M. Evans, B.G. Glover, and J.S. Moritz. Effects of enzyme supplementation on nutrient digestibility and growth performance of chicks fed diets containing meat and bone meal. Journal of Applied Poultry Research. (In Preparation) 
National Meeting Paper Presentations

National Meeting Poster Presentations

- 2015 Mid-Atlantic Nutrition Conference (Timonium, MD; Graduate Student) "Effects Of Modest Improvements In Pellet Quality And Experiment Pen Size On Broiler Chicken Performance."

\section{Other Research Experience}

- Led study examining the effects of feed form on tom turkey growth performance (Spring 2013)

- Led preliminary study examining the effects of feed form and pen size on broiler performance (Summer 2014)

- Led follow-up study on examining feed form effects and pen size on broiler performance (Spring 2015)

- Assisted study utilizing algae biomass in Cobb 500 broiler diets and its effect on live bird performance, ileal digestibility, and amino acid digestibility (Summer 2013)

- Assisted study utilizing poultry litter biochar (PLB) in Cobb 500 broiler diets and its effects on mineral sparing (Fall 2012)

- Assisted other studies funded by Verenium, DSm, Huvepharma, Aviagen, NuTech, Alltech

\section{TEACHING EXPERIENCE}

- Teaching Assistant for Poultry Production (ANPR 367)

- Teaching Assistant for Poultry Judging (Role includes lecturing occasionally in class) (ANPR 338)

\section{EDUCATION HONORS/AWARDS}

\section{Graduated from Pendleton County High School in 2009:}

- Beta Club Member (2008-2009)

- National Honor Society Member (2008-2009)

- Boys' Basketball Team Member (2005-2009)

- Golf Team Member (2008)

\section{Scholarships/Grants Received:}

- Promise Scholarship (2009-2010)

- Potomac State College Achievement Scholarship (2009-2010)

- Governors Honors Achievement (2009-2010) 
Animal specific courses taken:

-Intro to Animal Science 150

- Adv Evaluation- Animal Products

-Principles to Animal Science 251

- Beef Production 341,343

-Issues-Animal Science 480

- Poultry Production 367, 369

-Professional Field Experience 491

-Professions in Agriculture 112

- Intro to Animal Physiology 301

-Animal Nutrition 260

-Companion Animal Science 275

Graduate Courses:

- Introduction to Biochemistry 410

- Grants/Grantsmanship 593

- Nutrition/Disease Prevention 614

- Teaching Practicum 690

- Statistical Methods 511, 512

- Graduate Seminar 696

- Nutritional Biochemistry 512 